Ross, K. F. A. \& Billing, E. (1957). J. gen. Microbiol. 16, 418-425

\title{
The Water and Solid Content of Living Bacterial Spores and Vegetative Cells as Indicated by Refractive Index Measurements
}

\author{
By K. F. A. ROSS \\ Department of Biological Science, Wye College, University of London \\ AND EVE BILLING \\ Department of Bacteriology, National Agricultural Advisory Service, Wye, Kent
}

SUMMARY : Refractive index measurements were made on the spores and vegetative cells of strains of Bacillus cereus, $\boldsymbol{B}$. cereus var. mycoides and $\boldsymbol{B}$. megaterium by phase contrast and interference microscopy with protein immersion. The refractive indices of the spores were found to be very high and comparable with that of dehydrated protein, suggesting that they contained very little water. Those of the vegetative cells were much lower, and indicated a solid content of about $30 \%$, w/v.

Because of their relatively high resistance to heat and other lethal agents, it has long been thought probable that bacterial spores contain appreciably less water than the vegetative forms. Only a few attempts to measure the water content of spores or vegetative cells have, however, been described (Virtanen \& Pulkki, 1933; Henry \& Friedman, 1937), and the methods used, all of which involved bulk weighing and varying degrees of desiccation, were necessarily rather crude and imprecise.

Refractive index measurements can now be made on microscopical objects with considerable accuracy (e.g. Barer, Ross \& Tkaczyk, 1953; Mitchison \& Swann, 1953; Davies, Wilkins, Chayen \& La Cour, 1954; Ross, 1954; Barer \& Joseph, 1954), and, as was first pointed out by Davies \& Wilkins (1952) and by Barer $(1952 a)$, there is a close correlation between the refractive index of a cell and its water and solid content. It has been shown that the majority of substances found in living cells have approximately the same specific refraction increment $(\alpha)$ of $c .0 \cdot 0018$. This means that their combined refractive indices increase by about 0.0018 for every $1 \%$ rise in their $w / v$ concentration (Davies et al. 1954; Barer \& Joseph, 1954).

In the present work, the refractive indices of the vegetative cells and spores of three selected organisms were measured with a view to obtaining a more accurate indication of their water and solid content than hitherto.

\section{MATERIAL AND METHODS}

Cultures. The vegetative cells and spores measured were of single typical strains of Bacillus cereus, B. cereus var. mycoides, both isolated from milk, and B. megaterium (National Collection of Type Cultures 2607). All were grown on a $1 \%$ Lemco $1 \%$ peptone agar medium and incubated at $30^{\circ}$. 
Method of measuring the vegetative cells. The refractive indices of the vegetative cells from $18 \mathrm{hr}$. cultures were measured by the method of immersion refractometry first used by Barer \& Ross in 1952. The cells were suspended in a range of concentrations of protein in aqueous solution (bovine plasma albumin, fraction V, supplied by the Armour Laboratories, Eastbourne), of measured refractive index, and examined with a phase-contrast microscope. They then all appeared darker than the background when mounted in solutions having a lower refractive index than their own, and brighter in solutions of higher refractive index. In media with refractive indices approximating closely to that of the cells, they became almost invisible. This method is a very sensitive one, capable of detecting refractive index differences of $0 \cdot 001$, which is approximately equivalent to $\mathbf{0 . 5} \%$ of cell solids. It was found that the refractive indices of the individual vegetative cells varied by greater amounts than this, so that over a limited range of concentrations (in no case exceeding a refractive index range of 0.009 , or $5 \%$ of cell solids), dark and bright cells were both visible. 'The solution in which bright and dark cells were found to occur in approximately equal numbers was the one whose refractive index was taken as being equivalent to the mean refractive index of the cell population.

Method of measuring the spores. The method for the vegetative cells could not be used for the spores since it was found that their refractive indices were all higher than the most concentrated protein solutions obtainable, and nontoxic media of higher refractive index are difficult to find. Nevertheless, the fact that the middle of the spores all actually appeared bright under the phasecontrast microscope when they were mounted in water (Pl. 1, fig. 1), together with their small size, did indicate that the spores must have a considerably higher refractive index than the vegetative cells; because, with the particular phase plate used, this meant that the light passing through their maximum thickness was retarded by at least a quarter of a wavelength (Barer, 1952 b). It is not possible, however, actually to measure such retardations with a phasecontrast microscope.

Instead, an interference microscope was used to measure the retardations of light through the spores when mounted in two media of different refractive indices, and from these measurements their mean refractive index was calculated. A Smith interference microscope (manufactured by Messrs Charles Baker of Holborn) was used, and measurements were made with a $2 \mathrm{~mm}$. double focus objective in green light provided by a tungsten 'pointolite' lamp in conjunction with an Ilford 807 gelatin filter. The transmission of the filter with the light from this microscope lamp was investigated with a spectroscope, since these gelatin filters often show slight individual variations from the maker's specifications. It was found to give a narrow green band with a maximum intensity at $542 \mathrm{~m} \mu$., which was taken as being the mean wavelength of the light used.

The maximum retardation in phase of the light through the middle of each spore was measured by extinction point measurement, first in preparations mounted in distilled water (refractive index 1.334), (Pl. 1, figs. 2, 3), and then in concentrated aqueous protein solutions (which had varying refractive indices 
of about 1.40). The phase retardations of ten different spores were thus measured (as angles) in each of the two media, and the mean of each of the two sets of measurements taken.

The mean spore thickness was then calculated from the formula

$$
t=\frac{\phi_{1}-\phi_{2}}{\left(n_{2}-n_{1}\right) 360} \times \lambda
$$

where $t=$ the mean spore thickness (along the optical axis of the microscope) in $\mu$., $\phi_{1}=$ the mean phase retardation of the spores in water, $\phi_{2}=$ the mean retardation of the spores in the protein medium, $n_{1}=$ the refractive index of water $(1 \cdot 334), n_{2}=$ the refractive index of the protein medium, and $\lambda=$ the mean wavelength of the light used in $\mu \cdot(0 \cdot 542)$. The mean refractive index of the spores, $n_{s}$, was then calculated from the formula

$$
n_{s}=\left(\frac{\phi_{1}}{360} \times \frac{\lambda}{t}\right)+n_{1}
$$

This method was similar to that employed by Barer in 1953, except that the phase-change measurements, instead of being made on the same individual cells suspended successively in two media, were made on a different sample of spores in each medium. This was because of the experimental difficulty of completely replacing one mounting medium with another without washing all the spores out of the field.

\section{RESULTS}

Vegetative cells. The refractive indices of the individual vegetative cells of Bacillus cereus were all found to lie between $1 \cdot 3845$ and 1.3880 and they had a mean refractive index of $\mathbf{1 \cdot 3 8 6 5}$. The other two organisms were rather more variable; those of $B$. cereus var. mycoides lay between 1.3960 and 1.4030 with a mean of 1.4000 , and those of $B$. megaterium between 1.3830 and 1.3920 with a mean of $\mathbf{1} \cdot \mathbf{3 8 8 0}$.

Spores. The results of two sets of measurements on different cultures of the spores of each organism are shown in Table 1 . It will be seen that in each case the values for the mean thickness of the spores and their mean refractive index varied very little in the two successive experiments. The values for $\phi_{1}$ are all comparable since the mounting medium was water in every case, but the values for $\phi_{2}$ are not, because the refractive indices of the protein mounting media were different in the two experiments.

The accuracy of the values obtained. As has already been mentioned, the direct immersion and matching method used for measuring the refractive indices of the vegetative cells is very critical, and accurate to the nearest 0.001 which is less than the variation found in the refractive indices of the individual cells in each culture.

With the method used for the spores, it was not possible to obtain values for the refractive index of individual spores since, necessarily, different spores had to be measured in each medium. In deducing their mean refractive index, it 
was assumed that the mean phase change and thickness of the spore population behaved in essentially the same way as that of an individual spore.

Such an assumption would seem to be a reasonable one to make in the absence of evidence to the contrary, but circumstances can be envisaged where it might give rise to a certain degree of error in the values obtained for the mean refractive index of the population. This might happen, for instance, if the refractive indices of individual spores varied appreciably according to their thickness, as might occur in a population containing germinating spores, which are known to swell and imbibe water; but the material used contained only resting spores.

Table 1. The mean angular retardations of light, of wavelength $542 \mathrm{m \mu}$., through spores mounted in water and in protein solutions measured by the interference microscope and their mean thicknesses and refractive indices calculated therefrom

\begin{tabular}{|c|c|c|c|c|c|c|}
\hline \multirow[b]{3}{*}{$\begin{array}{l}\text { Refractive index of protein } \\
\text { medium }\left(n_{2}\right)\end{array}$} & \multicolumn{2}{|c|}{ B. cereus } & \multicolumn{2}{|c|}{$\begin{array}{l}\text { B. cereus var. } \\
\text { mycoides }\end{array}$} & \multicolumn{2}{|c|}{ B. megaterium } \\
\hline & Expt. 1 & Expt. 2 & Expt. 1 & Expt. 2 & Expt. 1 & Expt. 2 \\
\hline & $1 \cdot 3925$ & $1 \cdot 3960$ & $1 \cdot 3925$ & $1 \cdot 4000$ & $1 \cdot 3925$ & $1 \cdot 3880$ \\
\hline $\begin{array}{l}\text { Mean retardation in water } \\
\text { (degrees) (from } 10 \text { measure- } \\
\text { ments of different spores) }\left(\phi_{1}\right)\end{array}$ & $126 \cdot 8$ & $132 \cdot 8$ & $123 \cdot 6$ & $124 \cdot 6$ & $134 \cdot 0$ & $130 \cdot 2$ \\
\hline $\begin{array}{l}\text { Mean retardation in protein } \\
\text { (degrees) (from } 10 \text { measure- } \\
\text { ments of different spores) }\left(\phi_{2}\right)\end{array}$ & $84 \cdot 8$ & $87 \cdot 4$ & $86 \cdot 4$ & $79 \cdot 4$ & $95 \cdot 0$ & $96 \cdot 0$ \\
\hline Mean thickness in $\mu .(t)$ & 1.08 & $1 \cdot 10$ & 0.96 & $1 \cdot 02$ & 1.00 & 0.95 \\
\hline Mean refractive index $\left(n_{s}\right)$ & 1.521 & 1.513 & $1 \cdot 528$ & 1.519 & 1.537 & 1.540 \\
\hline
\end{tabular}

It was thought advisable to get additional evidence to support this assumption, and so an alternative method was also used to obtain approximate values for the refractive indices of individual spores in the case of Bacillus cereus. Spores of this organism were mounted in distilled water and the phase retardations through ten spores were measured in the same way as before, but the thickness of each spore was also measured as accurately as possible with an eyepiece micrometer. The refractive index of each spore, $n_{s}$, was then calculated from the formula

$$
n_{5}=\left(\frac{\phi_{1}}{360} \times \frac{\lambda}{t}\right)+n_{m}
$$

where $\phi_{1}=$ the phase retardation through each spore, $\lambda=$ the mean wavelength of the light used $\left(0.542 \mu\right.$.), $n_{m}=$ the refractive index of mounting medium $(\mathbf{1} \cdot 3340)$ and $t=$ the thickness of each spore estimated to the nearest $0 \cdot 2 \mu$. These measurements, and the refractive indices calculated from them, are shown in Table 2.

This method, however, is not a very critical one, and its accuracy is limited by the accuracy with which one can measure the spore thickness by direct measurement. With the $2 \mathrm{~mm}$. double focus objective used, it is very doubtful 
if the thicknesses were measured accurately to more than the nearest $0 \cdot 4 \mu$., and the final column of the table shows the limits of the refractive index of each spore assuming a maximum error of $\pm 0 \cdot 2 \mu$. in their measured thicknesses.

Table 2. Individual measurements of the maximum width and angular retardation of light of wavelength $542 \mathrm{m \mu}$. through spores of $\mathrm{B}$. cereus mounted in water, and the refractive indices of the spores calculated therefrom

\begin{tabular}{|c|c|c|c|c|}
\hline $\begin{array}{c}\text { Spore } \\
\text { no. }\end{array}$ & $\begin{array}{c}\text { Width (to the } \\
\text { nearest } 0 \cdot 2 \mu .) \\
\text { measured by } \\
\text { micrometer eyepiece } \\
(t)(\mu .)\end{array}$ & $\begin{array}{l}\text { Retardation } \\
\text { through spore } \\
\text { in water } \\
\text { (degrees) } \\
\left(\phi_{1}\right)\end{array}$ & $\begin{array}{l}\text { Refractive } \\
\text { index of } \\
\text { spore } \\
\left(n_{s}\right)\end{array}$ & $\begin{array}{l}\text { Range of refractive index } \\
\text { of spore, assuming a max. } \\
\text { error in width }(t) \text { measure- } \\
\text { ment of } \pm 0 \cdot 2 \mu \text {. }\end{array}$ \\
\hline 1 & 0.9 & 96 & 1.495 & $1 \cdot 466-1 \cdot 542$ \\
\hline 2 & $0 \cdot 9$ & 114 & 1.524 & $1 \cdot 490-1 \cdot 579$ \\
\hline 3 & $0 \cdot 9$ & 112 & $1 \cdot 521$ & $1 \cdot 488-1.576$ \\
\hline 4 & $1 \cdot 1$ & 128 & $1 \cdot 509$ & $1 \cdot 482-1 \cdot 549$ \\
\hline 5 & $1 \cdot 1$ & 120 & $1 \cdot 490$ & $1 \cdot 474-1 \cdot 534$ \\
\hline 6 & $1 \cdot 1$ & 124 & $1 \cdot 504$ & $1 \cdot 478-1 \cdot 541$ \\
\hline 7 & $1 \cdot 1$ & 126 & $1 \cdot 507$ & $1 \cdot 480-1 \cdot 544$ \\
\hline 8 & $\mathbf{1} \cdot \mathbf{1}$ & 134 & $1 \cdot 519$ & $1 \cdot 490-1 \cdot 558$ \\
\hline 9 & $1 \cdot 3$ & 150 & $1 \cdot 510$ & $1 \cdot 485-1 \cdot 539$ \\
\hline 10 & $1 \cdot 5$ & 176 & 1.511 & $1 \cdot 490-1 \cdot 538$ \\
\hline
\end{tabular}

(Range of refractive index of vegetative cells of $B$. cereus $1 \cdot 384-1 \cdot 388$.)

In spite of the relative inaccuracy of the method, however, two important conclusions can be drawn from these results.

(1) There appears to be no appreciable correlation between the refractive index and the thickness of the spores; and the fact that the phase change increases with the spore thickness suggests that the refractive indices of both the larger and smaller spores is similar. (The same kind of correlation between phase change and thickness was found in the cultures of Bacillus cereus var. mycoides and $B$. megaterium.)

(2) Even allowing for the relative inaccuracy of the method, it will be seen that the refractive indices of the spores are nevertheless all considerably greater than those of the vegetative cells.

It is also interesting to see that the average of these ten phase-change measurements is $128.0^{\circ}$ as compared with the values of 126.8 and $132.8^{\circ}$ obtained previously, and the average of their refractive indices is $1.509 \mathrm{com}-$ pared to the previous values of 1.512 and 1.513 (see Table 1 ). While too much should not be made of this, it does serve to indicate that the values obtained by the previous method are probably, in general, correct.

A further indication of the accuracy of the double-immersion method is given by the results obtained by using exactly the same technique to measure the mean refractive index of the vegetative cells of Lactobacillus bulgaricus (Ross, 1957, to be published). Here, the values obtained could be compared with those obtained by direct immersion refractometry, and it was found that, in nine separate cultures, these differed from each other and from those obtained by direct immersion and matching by a maximum of 0.0085 , which is equivalent to less than $\mathbf{5} \%$ of cell solids. 


\section{CONCLUSIONS AND DISCUSSION}

Water content. If one assumes that the mean refraction increment $(\alpha)$ of the dissolved substances in the vegetative cells is 0.0018 per $1 \%$ rise in concentration, the mean $\mathrm{w} / \mathrm{v}$ concentration of cell solids, $C$, can then be found from the formula (Barer, 1956):

$$
C=\frac{n_{c}-1 \cdot 334}{0 \cdot 0018},
$$

where $n_{c}=$ the mean refractive index of the vegetative cells. Table 3 shows the percentage of cell solids thus calculated. It also shows the percentage of water, assuming, first that the solids in the vegetative cells are composed predominantly of protein, and secondly that $1 \mathrm{~g}$. of protein occupies $\mathbf{0 . 7 5} \mathrm{ml}$. in aqueous solution, which is approximately true.

Table 3. Solid and water content of vegetative cells, spores and other materials calculated from refractive index measurements

\begin{tabular}{|c|c|c|c|c|}
\hline \multirow[b]{2}{*}{ Material } & \multirow[b]{2}{*}{$\begin{array}{l}\text { Mean } \\
\text { refractive } \\
\text { index }\end{array}$} & \multicolumn{2}{|c|}{ Assuming $\alpha=0.0018$} & \multirow{2}{*}{$\begin{array}{c}\text { Assuming } \\
\alpha=0.0015 \\
\text { Mean water } \\
\text { content } \\
\text { (in } \mathrm{g} . / 100 \mathrm{ml} .)\end{array}$} \\
\hline & & $\begin{array}{c}\text { Mean solid } \\
\text { content } \\
\text { (in } \mathrm{g} . / 100 \mathrm{ml} .)\end{array}$ & $\begin{array}{c}\text { Mean water } \\
\text { content } \\
\text { (in g./100 ml.) }\end{array}$ & \\
\hline \multicolumn{5}{|l|}{ Vegetative cells } \\
\hline B. cereus & $1 \cdot 386$ & $29 \cdot 0$ & $78 \cdot 0$ & - \\
\hline B. cereus var. mycoides & $1 \cdot 400$ & $36 \cdot 5$ & $72 \cdot 5$ & - \\
\hline B. megaterium & $1 \cdot 388$ & $30 \cdot 0$ & $77 \cdot 5$ & - \\
\hline \multicolumn{5}{|l|}{ Spores } \\
\hline B. cereus, Expt. 1 & $1 \cdot 512$ & $99 \cdot 0$ & $26 \cdot 0$ & $11 \cdot 0$ \\
\hline Expt. 2 & 1.513 & $99 \cdot 5$ & $25 \cdot 5$ & $10 \cdot 5$ \\
\hline \multicolumn{5}{|l|}{ B. cereus var. mycoides } \\
\hline Expt. 1 & $1 \cdot 528$ & $108 \cdot 0$ & $18 \cdot 0$ & $3 \cdot 0$ \\
\hline Expt. 2 & $1 \cdot 519$ & $102 \cdot 5$ & $23 \cdot 0$ & $7 \cdot 5$ \\
\hline B. megaterium, Expt. 1 & 1.537 & $113 \cdot 0$ & $15 \cdot 0$ & $-1 \cdot 5$ \\
\hline Expt. 2 & $1 \cdot 540$ & 114.5 & $14 \cdot 0$ & $-2 \cdot 5$ \\
\hline Leather & $1 \cdot 530 *$ & $109 \cdot 0$ & $18 \cdot 0$ & $1 \cdot 5$ \\
\hline Wool & $1 \cdot 540 *$ & $114 \cdot 5$ & $14 \cdot 0$ & $-2 \cdot 5$ \\
\hline Dried casein & $1 \cdot 540 *$ & $114 \cdot 5$ & $14 \cdot 0$ & $-2 \cdot 5$ \\
\hline
\end{tabular}

The exact interpretation, in terms of water and solid content, of the much higher values obtained for the refractive indices of the spores is more controversial, since it has been found that the results obtained from the extrapolation of formula (4) above do not accord exactly with the experimental evidence available (Davies et al. 1954; Barer \& Joseph, 1954; Barer, 1956). This suggests that the refractive index of dried protein may be rather lower than might be expected, and Davies et al. (1954) have suggested that the refraction increment $(\alpha)$ of dried protein may be as low as 0.0015 . It is certain, however, that these values indicate a very high content of solids, since they are comparable with the values obtained experimentally for the refractive indices of almost completely dehydrated protein products such as leather (1.53), wool and dried 
casein (both 1.54), quoted by Chamot \& Mason (1938), and they strongly suggest that the spores must contain very little water. Table 3 also shows the solid and water concentrations of the spores calculated on the same assumption used in the case of the vegetative cells. It is quite possible, however, that the values for the water content thus calculated are rather too high, and the final column of the table shows the even lower values obtained assuming the refraction increment of 0.0015 suggested by Davies et al. 1954. This method is, of course, only capable of indicating the total water content of the spores. It is not capable of showing whether, as was suggested by Friedman \& Henry in 1938, a proportion of this occurs as 'bound water'.

Previous measurements of the water content of vegetative cells and spores. Henry \& Friedman (1937) estimated the water content of the spores and vegetative cells of two of the three organisms used in the present investigation from bulk weighing and drying. A known weight of each organism, which had previously been blotted with filter paper, was air-dried, desiccated over $\mathrm{CaCl}_{2}$, and finally oven-dried; and it was reweighed at each stage. They found that, throughout the whole process, the spores of Bacillus megaterium lost $58 \%$ by weight of water and those of $\boldsymbol{B}$. cereus var. mycoides $71 \%$; while the vegetative cells of $B$. megaterium lost $80 \%$, and those of $B$. cereus var. mycoides $88 \%$. Although the method was almost certainly too crude for these figures to be regarded as being at all reliable absolute values, they do accord with the results of the present investigation in as far as they indicate that the spores contained appreciably less water than the vegetative cells.

Henry \& Friedman did not, however, base their final estimation of water content on the overall loss of weight, but only on the percentage loss of weight between the stages of air drying and oven drying. The reason for their doing this is not altogether clear, for although, as they themselves point out, neither the blotted nor the air dried cells were very satisfactory starting materials, the former would seem to have been preferable in so far as the vegetative cells were probably mostly still intact, which they were unlikely to have been after air drying. The conclusion they consequently drew, to the effect that both the spores and the vegetative cells contained similar amounts of water (c. 16\%), is almost certainly incorrect.

Powell \& Strange (1953) have also expressed the opinion that the water content of spores must be extremely low, and some preliminary weighing experiments of their own, with Bacillus subtilis, supported this view.

The Smith interference microscope used in this work was provided out of a grant to one of us (K.F.A.R.) from the London University Central Research Fund.

We are also much indebted to Dr J. R. Baker of the Cytological Laboratory, Department of Zoology, Oxford, and Mr F. H. Smith of Messrs Charles Baker of Holborn for kindly undertaking to read our manuscript and offer useful suggestions. 

Journal of General Microbiology, Vol. 16, No. 2
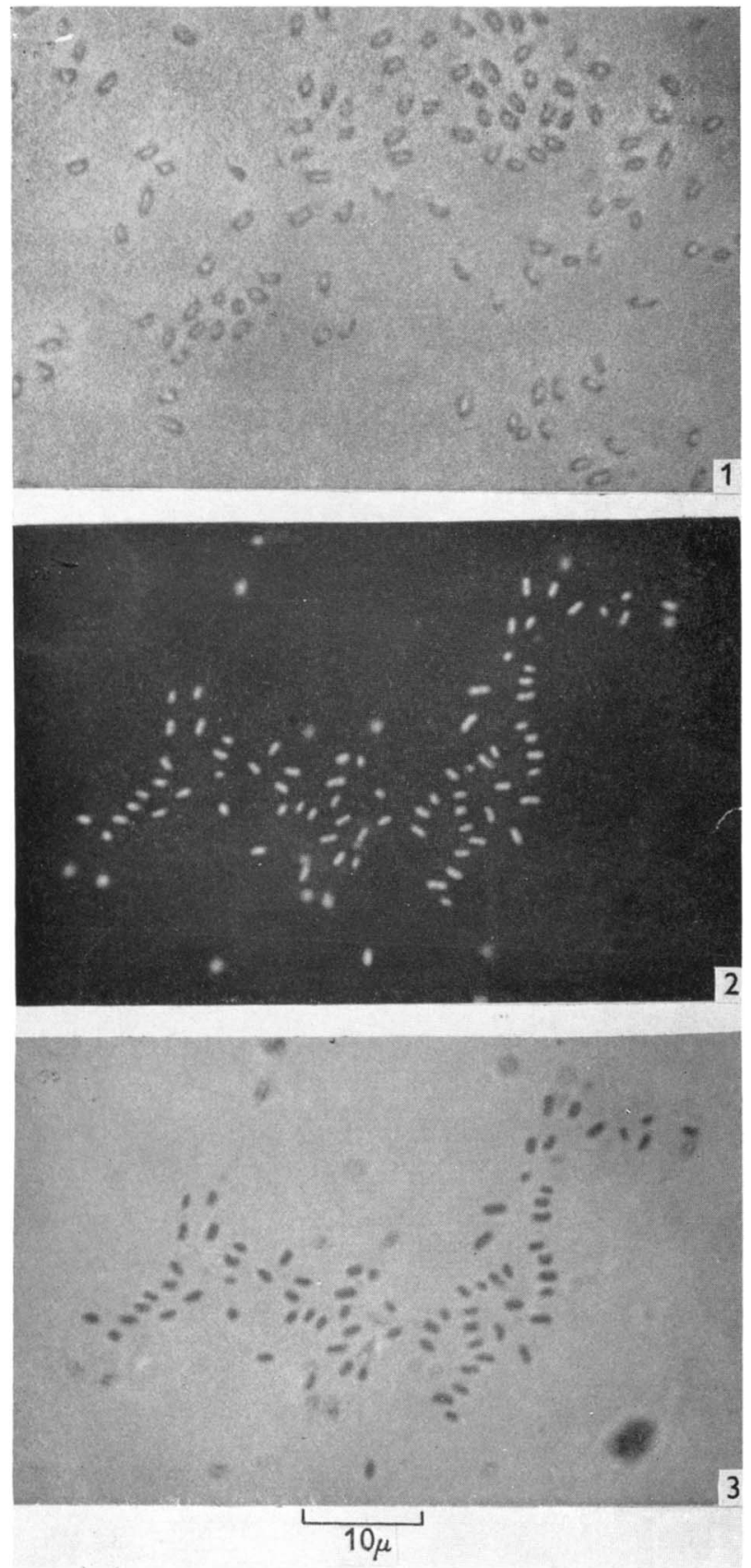

K. F. A. Ross axd E. Billing-The water content of bactenia and spores. Plate 1 


\section{REFERENCES}

BARER, R. (1952a). Interference microscopy and mass determination. Nature, Lond. 169, 366.

BARER, R. (1952b). A vector theory of phase contrast and interference contrast. J. R. micr. Soc. 72, 10.

BARER, R. (1953). Determination of dry mass, thickness, solid and water concentration in living cells. Nature, Lond. 172, 1097.

BARER, R. (1956). 'The interference microscope in quantitative cytology. Supplement to 'The Baker Interference Microscope' (1955). London: C. Baker of Holborn Ltd.

BARER, R. \& Joseph, S. (1954). Refractometry of living cells. I. Quart. J. micr. Sci. 95, 399.

Barer, R. \& Ross, K. F. A. (1952). Refractometry of living cells. J. Physiol. 118, $38 P$.

Barer, R., Ross, K. F. A. \& Tkaczyk, S. (1953). Refractometry of living cells. Nature, Lond. 171, 720.

Сhamot, E. M. \& Mason, C. W. (1938). Handbook of Chemical Microscopy, vol. 1, 2nd ed. London: Chapman and Hall.

Davies, H. G. \& Wilkins, M. H. F. (1952). Interference microscopy and mass determination. Nature, Lond. 169, 541.

Davies, H. G., Wilkins, M. H. F., Chayen, J. \& LA Covr, L. F. (1954). The use of the interference microscope to determine dry mass in living cells and as a quantitative cytochemical method. Quart. J. micr. Sci. 95, 271.

Friedman, C. A. \& Henry, B. S. (1938). Bound water content of vegetative and spore forms of bacteria. J. Bact. 36, 99.

Henry, B. S. \& Friedman, C. A. (1937). The water content of bacterial spores. J. Bact. 33, 323.

Mrtchison, J. M. \& Swann, M. M. (1953). Measurements on sea urchin eggs with an interference microscope. Quart. J. micr. Sci. 94, 381.

Powell, J. F. \& Strange, R. E. (1953). Biochemical changes occurring during the germination of bacterial spores. Biochem. J. 54, 205.

Ross, K. F. A. (1954). Measurement of the refractive index of cytoplasmic inclusions in living cells by the interference microscope. Nature, Lond. 174, 836.

Virtanen, A. I. \& Pulkki, L. (1933). Biochemische Untersuchungen über Bakteriensporen. Arch. Microbiol. 4, 99.

\section{EXPLANATION OF PLATE}

Fig. 1 was taken with a Watson phase-contrast microscope with a $2 \mathrm{~mm}$. fluorite objective and a $25 \%$ absorbing $90^{\circ}$ positive phase plate. Figs. 2 and 3 were taken with a Smith interference microscope with a $2 \mathrm{~mm}$. 'double focus' objective and an Ilford 807 (mercury green) filter. The scale, indicated at the bottom of the page, is the same for all the photographs.

Fig. 1. Phase-contrast photograph of the spores of $B$. cereus mounted in water. The centres of the spores appear bright, indicating that they are appreciably more refractile than the vegetative cells.

Fig. 2. Photograph with the interference microscope of the spores of B. cereus mounted in water with the analyser goniometer set at $145^{\circ}$. At this setting the field appears maximally dark.

Fig. 3. The same preparation as in Fig. 2 with the goniometer analyser set at $80^{\circ}$. A number of the spores now appear maximally dark. The rotation of the analyser from the position in Fig. 2 represents a phase retardation of $130^{\circ}$.

(Received 12 October 1956) 